\title{
Opieka koordynowana, definicja, mięlzynarodowe doświadczenia jako inspiracja dla Polski
}

\section{Anna Kozieł ${ }^{1}$, Aleksandra Kononiuk ${ }^{1}$, Katarzyna Wiktorzak ${ }^{2}$}

\author{
${ }^{1}$ Bank Światowy (The World Bank) \\ ${ }^{2}$ Narodowy Fundusz Zdrowia
}

Adres do korespondencji: Anna Kozieł, Bank Światowy, 00-113 Warszawa, ul. Emilii Plater 53, akoziel@worldbank.org

\section{Abstract}

\section{Coordinated care, definition, international experience as an inspiration for Poland}

Integrated care could be seen as an approach to overcome deficiencies in the care management for people with chronic diseases and frail elderly, while at the same time improving efficiency, quality and effectiveness of the health services provided. In the recent years, focus has been on better coordination and integration among health sectors to manage specific diseases. The solutions we see across the world present integration between levels of care in health but also social sector. New solutions necessitate the overcoming of many boundaries, most notably between different professions, different organizations and different attitudes in both sectors.

The many experiences across Europe and around the world have demonstrated that sustainable solutions need a multi-faceted approach, which changes the processes and structures of service delivery just as much as the culture and attitudes of all stakeholders involved. Patients, families and communities need to be actively involved in this process in order to ensure that their needs are met.

This article gives an overview of the different examples of the definition and implementation elements of the integrated care and how could Poland benefit from those.

\section{Key words: coordinated care, coordinated care models, coordinated care proyrams}

Stowa kluczowe: opieka koordynowana, programy i modele opieki koordynowanej

\section{Wstẹp}

Celem pracy było wskazanie różnorodności w podejściu do zagadnień opieki koordynowanej (OK), zarówno jeżeli chodzi o jej definicje, funkcjonalność, jak również skalę, sposób wdrożenia oraz znaczenie dla systemu ochrony zdrowia i pacjentów. Wśród analizowanych programów OK częściej spotykane są te obejmujące osoby starsze lub różne formy zarządzania chorobą oraz wdrażane na poziomie regionalnym [1, 2]. Różnorodność ma istotne znaczenie przy wdrażaniu projektów opieki koordynowanej w Polsce. Pokazuje bowiem, że nie ma jednego, właściwego, sprawdzonego w wielu krajach na świecie modelu opieki koordynowanej. Jedną z nielicznych cech wspólnych dla przykładów opieki koordynowanej w różnych krajach jest to, że jest ona różnorodna, mocno dostosowana do potrzeb lokalnych, często wdrażana na małą skalę. Inspiracją więc może być to, że w przedsięwzięciach związanych z opieką koordynowaną ważna jest dogłębna analiza sytuacji i potrzeb lokalnych oraz oddolne (wspólne z właściwymi podmiotami wdrażającymi) tworzenie modelu opieki koordynowanej.

Istnieje kilka cech opieki koordynowanej, które da się zauważyć w literaturze światowej. Dotyczą one zakresu świadczeń, mechanizmów płatności, zakresu chorób czy typu pacjentów objętych opieką, jako że trudno jest porównywać bardzo różnorodne programy. W artykule przedstawione są również główne wnioski z procesów wdrażania.

Praca ma także na celu wskazanie pewnych źródeł wiedzy być może przydatnych przy wdrażaniu inicjatyw związanych z opieką koordynowaną w Polsce. Od kilku lat prowadzone są prace i wdrożenie projektów opieki koordynowanej w opiece nad matką i dzieckiem, 
rehabilitacji medycznej, opiece nad chorymi na SM czy podstawowej opiece zdrowotnej. Definicje i przykłady zawarte $\mathrm{w}$ tej pracy mogą wesprzeć systemowe podejście od wprowadzanych rozwiązań.

\section{Metoda badlawcza}

Opieka koordynowana, mając tak wiele znaczeń, nie może być rozpatrywana dogłębnie bez kontekstu systemowego danego kraju. Podane poniżej przykłady mają więc charakter poglądowy, ze świadomością, że nie wyczerpują one tematu. Praca powstała na podstawie systematycznego przeglądu literatury naukowej oraz dostępnych informacji opisujących przykłady przedsięwzięć opieki koordynowanej. Przykłady wybrano tak, aby wskazywały one na różnorodność rozwiązań oraz systemów, w których opieka koordynowana funkcjonuje.

\section{Definicja}

Zgodnie z definicją przygotowaną przez Europejskie Biuro Światowej Organizacji Zdrowia (WHO EURO) [3], opieka koordynowana to „koncepcja świadczeń związanych z diagnozowaniem, leczeniem, opieką, rehabilitacją i promocją zdrowia w wymiarze nakładów, realizacji i organizacji świadczeń oraz zarządzania”. Koordynowana opieka zdrowotna prowadzi do poprawy dostępności, jakości oraz efektywności opieki, a także poziomu satysfakcji pacjenta. Z praktycznej perspektywy zintegrowany system realizacji świadczeń można określić mianem bliskich, roboczych relacji między różnymi służbami i usługami, takimi jak: szpitale, policja, opieka domowa, zdrowie publiczne, opieka społeczna i inne świadczenia związane ze zdrowiem.

Opieka koordynowana nie jest końcowym rezultatem, lecz istotnym czynnikiem wpływającym na poprawę jakości opieki. Istnieją obszerne badania przedstawiające różne elementy i definicje takiej opieki [4], odsłaniające różne perspektywy mające wpływ na projektowanie i kształt procesu zmian.

Definicja opracowana przez Kodnera i Spreeuwenberga [5]:

\footnotetext{
„Koordynacja jest spójnym zestawem metod i modeli na poziomach finansowania, administrowania, organizacji, świadczenia usług oraz na poziomie klinicznym, zaprojektowanym w celu stworzenia łączności, ujednolicenia i pobudzenia współpracy wewnątrz i pomiędzy sektorami leczenia i opieki. Celem tych metod i modeli jest polepszenie jakości opieki i życia, satysfakcja pacjenta oraz efektywność systemu (...). Tam, gdzie tego typu wielotorowe wysiłki promujące integrację prowadzą do osiągania korzyści przez świadczeniobiorców, rezultat można określić mianem «opieki koordynowanej»".
}

Inne funkcjonujące określenia to między innymi opieka skoncentrowana na pacjencie (patient's cantered care), opieka zintegrowana (integrated care), opieka dzielona między różne osoby lub podmioty (shared care), opieka współpracująca (collaborative care) [4, 6-15]. Część $\mathrm{z}$ tych określeń używana jest wymiennie, mimo że nie zawsze oznaczają dokładnie to samo.
Opieka koordynowana (lub zintegrowana) to także: metody i sposoby organizacji opieki umożliwiające udzielanie świadczeń profilaktycznych i leczniczych wysokiej jakości, a jednocześnie opłacalnych, zapewniających ciągłość i koordynację leczenia z przeznaczeniem dla pacjentów o największych potrzebach zdrowotnych [16]; system łączący opiekę zdrowotną (doraźną, podstawową i specjalistyczną) z opieką socjalną/środowiskową (opieką długoterminową, domową, edukacją) w celu poprawy wydajności systemu i wyników leczenia [17]; system spajający w całość nakłady, personel itd., niezbędne do stworzenia systemu, udzielania świadczeń, organizacji i zarządzania opieką związaną z rozpoznaniem choroby, leczeniem, rehabilitacją i promocją zdrowia, aby zwiększyć dostępność i jakość opieki, satysfakcję pacjenta i wydajność systemu [18]; modele płatności, organizacji systemu, udzielania świadczeń i ścieżek zawodowych personelu medycznego sprzyjające współpracy, spójności i konsolidacji powiązań między poziomami opieki przyczyniające się do wzrostu jakości opieki i życia pacjentów oraz wydajności systemu [5].

Klasyfikację opieki koordynowanej (zintegrowanej) można przedstawić także poprzez następujące funkcje [19-21]:

- integracja funkcjonalna, czyli koordynacja na poziomie niezwiązanym bezpośrednio z udzielaniem świadczeń (finansowanie, informowanie, zarządzanie);

- integracja organizacji, czyli koordynacja opieki między instytucjami;

- integracja interdyscyplinarna jako tworzenie interdyscyplinarnych zespołów;

- integracja świadczeń, czyli koordynacja świadczeń w ramach pojedynczego procesu terapeutycznego;

- integracja normatywna jako określenie wspólnych norm i wartości oraz kierowanie się nimi przy realizacji świadczeń;

- integracja systemowa jako dopasowanie strategii i systemu motywacyjnego na poziomie organizacyjnym.

Koordynacja opieki, aby była skuteczna i długotrwała, musi odbywać się na wszystkich poziomach systemu. Mimo iż opracowany przez Valentijna i wsp. [22] model tęczy ${ }^{1}$ rozpatruje opiekę koordynowana w kontekście Holandii z perspektywy podstawowej opieki zdrowotnej, to jednak model ten wciąż jest użytecznym narzędziem, które umożliwia analizowanie różnych poziomów systemu ochrony zdrowia, a do tego pozwala określić, co należy zmienić, połączyć lub skoordynować, aby uzyskać lepsze wyniki.

Valentijna i wsp. [23] utrzymują, że koordynacja na wszystkich poziomach (kliniczna, profesjonalistów, organizacyjna i systemowa) w rezultacie prowadzi do powstania systemu opieki, który skupia się na potrzebach świadczeniobiorcy i populacji. Badacze zwracają uwagę na to [24], że świadczeniobiorcy, ich rodziny, opiekunowie oraz społeczności stanowią także oddzielny, pełnoprawny poziom, który należy uwzględnić w koordynacji i zmianie postaw.

Kodner [5, 25] pisze także o koordynacji na poziomie:

- finansowania rozumianego jako konsolidacja funduszy na różnych poziomach; 
- administracji jako konsolidacji zadań;

- instytucji jako planowania i zarządzania budżetem w ramach grupy świadczeniodawców;

- udzielanych świadczeń, czyli koordynacji leczenia;

- ewaluacji rozumianej jako jednolite i kompleksowe procedury ewaluacyjne.

Można także przedstawić stopnie koordynacji [17] na trzech poziomach:

1. jak najmniej zmian - współpraca doraźna;

2. koordynacja w ramach istniejących struktur - określa mechanizmy ułatwiające komunikację i wymianę informacji między podmiotami;

3. pełna koordynacja - stworzenie nowej instytucji/ systemu, obejmujących wszystkie zadania, zasoby i finansowanie.

Kluczową cechą opieki koordynowanej jest jej różnorodność w zależności od poziomu aktywności i stopnia integracji. Mimo że opieka koordynowana może w systemach opieki zdrowotnej przybierać różne formy, cechą wspólną jest to, że luki w integracji na jednym poziomie mogą mieć negatywny wpływ na integrację na pozostałych poziomach. Przykładem takiej współzależności jest związek między opieką medyczną świadczoną w trybie ostrym a pierwszym punktem kontaktowym dla pacjenta wchodzącego do systemu opieki: gdy podstawowa opieka zdrowotna (POZ) dobrze pełni funkcję „strażnika” oceniającego sytuację i kierującego pacjenta na dalsze szczeble systemu, z szybko stawianą diagnozą, obciążenie na poziomie opieki w trybie ostrym będzie mniejsze [26].

Pomimo braku jednoznacznej definicji zdecydowana większość programów opieki koordynowanej ma ten sam cel - wspieranie osób chorych przewlekle. Rezultatem tych programów bardzo często jest ograniczenie liczby hospitalizacji (nawet o 19\%) i zwiększenie satysfakcji pacjentów [27].

Szczegółowe cele opieki koordynowanej określone w wielu programach na całym świecie to:

- udoskonalenie procesu tworzenia i świadczenia opieki zdrowotnej zorientowanej na pacjenta;

- podniesienie jakości świadczeń dla osób w podeszłym wieku, przewlekle chorych i niepełnosprawnych;

- zmniejszenie fragmentaryzacji, wypełnienie luki i usunięcie nadwyżki/zwiększenie efektywności wykorzystania posiadanych zasobów;

- zapewnienie ciągłości i koordynacji leczenia;

- zapobieganie błędom medycznym;

- zwiększenie satysfakcji społeczeństwa z systemu opieki zdrowotnej i procesów leczenia;

- zwiększenie efektywności kosztowej prowadzonych procesów.

\section{Wybrane przykładly mięlzynarodowe}

$\mathrm{Na}$ całym świecie istnieją inicjatywy opieki zorientowanej na pacjenta, większej koordynacji nie tylko pomiędzy poziomami opieki, ale także sektorami opieki (na przykład zdrowie i sektor społeczny) [28]. Przykładów jest bardzo wiele, jednak tylko część z nich jest rygorystycznie oceniona. Nie zmienia to jednak faktu, że doświadczenia międzynarodowe mogą stanowić inspirujące źródło informacji i wiedzy dla rozwoju systemu dostarczania usług zdrowotnych w Polsce.

W analizie 85 badań dotyczących opieki koordynowanej z sześciu krajów OECD potwierdzono, że opieka koordynowana daje dobre wyniki leczenia i wysoką satysfakcję pacjenta, zwłaszcza przy zastosowaniu kilku strategii, jak na przykład narady dotyczące danego przypadku, plany opieki, szkolenia czy finansowanie koordynacji [29].

Analizując 15 randomizowanych badań klinicznych przeprowadzonych w USA wśród beneficjentów programu Medicare, zaobserwowano, iż koszty opieki koordynowanej są wyższe niż koszty leczenia w grupie kontrolnej, choć w większości przypadków różnice te nie były istotne; dowiedziono, iż pacjentom z grupy opieki koordynowanej udzielano więcej informacji na temat ich choroby i otrzymywali oni większą pomoc w zorganizowaniu opieki [30].

Wykazano także wpływ organizacji opieki nad osobami przewlekle chorymi na prawdopodobieństwo hospitalizacji u osób po zawale mięśnia sercowego. Prawdopodobieństwo to było niższe, jeśli opieka planowana była przez zespół interdyscyplinarny, a pacjenci mieli osobisty kontakt ze świadczeniodawcami (w zestawieniu z kontaktem telefonicznym) [31].

Choć wydaje się, iż dzięki opiece koordynowanej zmniejsza się liczba przypadków hospitalizacji, jej wpływ na koszty pozostaje niezmierzony, zwłaszcza w dłuższej perspektywie. Niemniej jednak w niektórych badaniach wskazano programy opieki koordynowanej przynoszące oszczędności. Są to programy stworzone (I) dla pacjentów na przykład z zastoinową niewydolnością mięśnia sercowego, czy (II) pacjentów z dużymi potrzebami zdrowotnymi $[5,32]$.

Niemcy są dobrym przykładem rozwiązań proponujących elementy opieki koordynowanej. Reforma państwowego ubezpieczenia zdrowotnego przeprowadzona w 2002 roku wprowadziła programy opieki dla konkretnych chorób, aby polepszyć profilaktykę i koordynację leczenia chorób przewlekłych. Miało to skutkować lepszą jakością usług i pobudzać konkurencję między kasami chorych. Wprowadzono je w kontekście starzejącego się społeczeństwa, wzrostu zapadalności na choroby przewlekłe i braku kontroli nad działaniami świadczeniodawców czy stosowania wytycznych dobrych praktyk. Niemiecki system to przykład programu integracji „poziomej” w połączeniu z umiarkowaną koordynacją, nacisk na integrację na poziomie organizacyjnym, udzielanie świadczeń z zakresu opieki; rolę koordynatorów przyjęli lekarze POZ.

W Niemczech, między innymi w Gesundes Kinzingtal $(\mathrm{GK})^{2}$, prowadzony jest także model opieki koordynowanej, gdzie ważną rolę odgrywa ubezpieczyciel. Opieka koordynowana w GK została stworzona jako program pilotażowy przygotowany przez sieć lokalnych lekarzy i firmę zarządzającą opieką zdrowotną. Założenie było takie, żeby stworzyć lokalny rynek dostarczania usług zdrowotnych poprzez lepsze wyniki zdrowotne i efektywniejsze wydawanie dostępnych środków - racjonalizację procesów i wydatków. Twór- 
com programu chodziło także o podwyższenie jakości dostarczanych usług. Wyjątkowym elementem w GK było podejście populacyjne, obejmujące całą populację w regionie. W rezultacie rozszerzenia działań pilotażu jedna trzecia ubezpieczonych zapisała się do opieki koordynowanej oferowanej przez GK. Opiekę oferuje 160 dostarczycieli (głównie lekarze, ale także szpitale, pielęgniarskie domy opieki) [5]. Jednym z kluczowych rozwiązań stosowanych przez GK jest kontraktowanie pozwalające na dzielenie się oszczędnościami pomiędzy dostarczycielami świadczeń [33]. Podobne rozwiązania stosowane są także na przykład w Stanach Zjednoczonych (CareFirst) [34].

Kolejnym krajem z przykładami inicjatyw w opiece koordynowanej jest Holandia. W roku 2006 wprowadzono w Holandii system ryczałtowy - konkurencję regulowaną między ubezpieczycielami i świadczeniodawcami. Do 2010 roku 90\% populacji Holandii podpisało umowę z jednym z czterech głównych ubezpieczycieli, natomiast sześciu mniejszych założyło spółdzielnię nabywców. W roku 2007 eksperymentalnie wprowadzono ryczałt za leczenie cukrzycy. W roku 2010 rozszerzono zakres opieki opłacanej ryczałtem o trzy schorzenia, takie jak: przewlekła obturacyjna choroba płuc (POChP), zawał mięśnia sercowego i postępowanie w wypadku wystąpienia czynników ryzyka chorób układu krążenia ze względu na wysoki wskaźnik zachorowalności i praktyczne możliwości wprowadzenia tego rozwiązania. Na przykładzie Holandii można zaobserwować elementy koordynacji „pionowej” o umiarkowanym stopniu, z naciskiem na koordynację na poziomie organizacyjnym, udzielania świadczeń i zakresu opieki; główną rolę odgrywają lekarze POZ. W holenderskim Geriant [35] zaproponowano duże wsparcie zespołu interdyscyplinarnego. Dzięki temu pacjenci z otępieniem starczym dłużej pozostawali w swoich domach.

HealthOne (Australia) [35] wprowadziło lepsze planowanie i koordynację opieki nad osobami starszymi z dużymi potrzebami zdrowotnymi. Pacjenci byli odpowiednio prowadzeni przez system i powiązani z właściwymi świadczeniodawcami, co przełożyło się na mniejszą liczbę niepotrzebnych hospitalizacji.

W PRISMA (Kanada) [35] jako jeden z elementów zmiany opieki na zorganizowaną wokół pacjenta wdrożona została koordynacja opieki przy użyciu danych uzyskiwanych w czasie rzeczywistym i przepływ informacji pomiędzy personelem. Dzięki temu opieka była bardziej efektywna, udzielana wcześniej i szybciej. Dodatkowym elementem sukcesu było wprowadzenie funkcji koordynatora jako jednej osoby kontaktowej i prowadzącej pacjenta przez system, a także koordynującej dostarczane mu usługi.

W Whiringa Ora (Nowa Zelandia) [35] jako dodatkowy element wspierający opiekę koordynowaną zaproponowano edukację. Nacisk na edukację i pomoc w odzyskaniu samodzielności spowodował, że przewlekle chorzy lepiej radzili sobie z chorobą, a liczba hospitalizacji w tej grupie spadła. Opieka samodzielnie prowadzona przez pacjenta (self care) jest także jednym z ważnych narzędzi wspierających wdrożenie opieki koordynowanej [36].
Norrtalje (Szwecja) [35] jest przykładem koordynacji w zakresie komunikacji, dzięki której świadczona była efektywna, intensywna opieka domowa dostarczana wcześniej i w krótszym czasie. Pacjenci tym samym pozostawali dłużej we własnych domach, a liczba osób starszych przyjmowanych do domów opieki spadła.

Wielka Brytania ma szerokie i wieloletnie doświadczenie we wdrażaniu opieki koordynowanej na różnych poziomach, w tym także pomiędzy sektorem zdrowotnym i społecznym (w Szkocji). W Torbay [35] wprowadzono koordynację opieki nad osobami starszymi, w wyniku której zmniejszyła się liczba przypadków ostrych wymagających hospitalizacji, pacjenci dłużej pozostawali we własnych domach, a liczba osób przyjmowanych do domów opieki spadła.

Podobnie jak Wielka Brytania Stany Zjednoczone są źródłem różnorodnych, często innowacyjnych modeli koordynacji. Znaczna część z nich jest także metodą racjonalizacji kosztów zdrowotnych. W MassGeneral (USA) [35] wprowadzono koordynację intensywnej opieki nad pacjentami generującymi wysokie koszty. Silny nacisk na samodzielność i bliską współpracę z lekarzami POZ poskutkował spadkiem liczby ostrych przypadków wymagających hospitalizacji w tej grupie, a tym samym oszczędnościami w systemie.

Aby opieka nakierowana na pacjenta mogła być realnie wdrożona oraz przynosiła zamierzone rezultaty, powinny być uruchomione działania na poziomie systemowym, organizacyjnym czy właściwej komunikacji. $\mathrm{Z}$ punktu widzenia systemowego istotne jest wsparcie zewnętrzne w postaci odpowiedniego finansowania rozwoju lokalnych inicjatyw opieki koordynowanej przy jednoczesnym unikaniu odgórnego podejścia wymuszającego łączenie podmiotów na poziomie strukturalnym lub organizacyjnym. Samo usunięcie barier administracyjnych czy prawnych utrudniających koordynację opieki w danym regionie, na przykład różnych modeli finansowania czy wymogów, może przynieść wymierne skutki.

W związku z brakiem jednoznacznej definicji opieki koordynowanej oraz dużymi różnicami systemowymi między krajami czy też regionami [37] wydaje się zasadne wdrażanie wielu różnych modeli opieki koordynowanej, dostosowanych do regionu i populacji. Punktem wyjścia powinno być ulepszenie już świadczonej opieki, a nie wprowadzanie nowego, sztywnego modelu. Istotnym elementem organizacyjnym zmian powinna być świadomość dostosowywania modeli do zmieniającej się rzeczywistości.

W międzynarodowych doświadczeniach z wdrażaniem opieki zintegrowanej jednym z głównych celów jest promowanie opieki koordynowanej poza szpitalami, na przykład w ramach opieki ambulatoryjnej i długoterminowej [38].

Działania polegające na zorganizowaniu pracy i specjalistów różnych dziedzin wokół potrzeb pacjenta są cechami opieki koordynowanej. Zapewnienie właściwych osób zajmujących się pacjentem, koordynacja tej pracy czy szybka wymiana informacji pomiędzy wszystkimi osobami opiekującymi się pacjentem są bardzo istotne. Niezwykle ważna jest elastyczność w ramach zespołu 
pracującego z pacjentem oraz uprawnienia dające pracownikom możliwość zamiany ról w razie potrzeby.

Bardzo istotnym elementem wdrażania opieki koordynowanej jest sprawna komunikacja. Dobra komunikacja i relacje między pacjentami, personelem medycznym/opieki socjalnej i koordynatorami są warunkiem sukcesu. Dzięki temu zmiana systemowa następuje także poprzez budowanie nowych relacji i kapitału społecznego. Rozwój systemów opieki koordynowanej i dojście do fazy dojrzałości systemu jest procesem wymagającym czasu.

Niezbędne jest szersze zastosowanie systemów telekomunikacyjnych i nowoczesnych rozwiązań IT pozwalających na analizę procesów, jakości i wydatków [38].

$\mathrm{Z}$ doświadczeń międzynarodowych wynika, że koordynowany system dostarczania usług zapewnia takie działania, jak: planowanie opieki, jeden punkt rejestracji, koordynacja opieki, sieć podmiotów ściśle z sobą współpracujących, co ułatwia dostęp do wymaganego wsparcia, na przykład w odzyskaniu samodzielności.

$\mathrm{Z}$ punktu widzenia pacjenta $\mathrm{w}$ modelach międzynarodowych kładziono duży nacisk na pracę z pacjentem i jego opiekunami, aby zwiększyć jego samodzielność. Lepsze skutki przynosi kontakt osobisty ze znanym z imienia i nazwiska koordynatorem opieki i/lub menedżerem (osobą wyznaczoną do zarządzania danym „przypadkiem”) niż monitorowanie na odległość czy wsparcie telefoniczne. Wydaje się, że skuteczność działań poprawia się, gdy celem jest zapewnienie pacjentowi dobrostanu/niezależności w codziennym funkcjonowaniu i wspieranie go w taki sposób, aby mógł sobie radzić ze schorzeniem i prowadzić dobre życie, w odróżnieniu od podejścia nastawionego wyłącznie na ograniczanie/leczenie objawów. Świadczeniobiorców zdecydowanie powinno się angażować w proces zarządzania chorobą poprzez samokontrolę i rozmaite pakiety wsparcia dostosowane do ich potrzeb [38].

Plany opieki powinny być „szyte na miarę”, to jest dostosowane do indywidualnych potrzeb danego użytkownika. Nie należy z góry narzucać wcześniej opracowanego planu opieki, ponieważ potrzeby pacjenta mogą z czasem ewoluować, a wraz z nimi powinien elastycznie zmieniać się tryb realizacji świadczeń [38].

Proces wdrażania był tym elementem, który udało się przebadać na tyle szeroko, aby móc wyciągnąć systematyczne wnioski. Wdrożenie podzielono na poziom funkcjonalny, systemowy, organizacyjny i osobisty [38]. $\mathrm{Z}$ analiz wynika między innymi, że:

- Aby zbudować relacje potrzebne do dobrego funkcjonowania opieki koordynowanej, trzeba czasu, kapitału społecznego oraz zaufania (na poziomie funkcjonalnym, ale także systemowym).

- Podejście oddolne, niewymagające od samego początku fuzji organizacyjnych lub strukturalnych, sprawdza się lepiej niż odgórne narzucanie (na poziomie funkcjonalnym, ale także systemowym).

- W zarządzaniu pozytywne wyniki daje podejście populacyjne w celu kompleksowego zbadania potrzeb i priorytetów określonej populacji geograficznej.
- Rozwój systemów opieki koordynowanej i dojście do fazy dojrzałości systemu jest procesem wymagającym czasu.

- Przedstawiciele zawodów medycznych, zarówno na poziomie medycyny ogólnej, jak i specjalizacji, muszą z sobą współpracować w ramach wielodyscyplinarnych zespołów lub sieci świadczeniodawców, tak w opiece zdrowotnej, jak i pomocy społecznej.

- Niezwykle istotna jest elastyczność w ramach zespołu pracującego $\mathrm{z}$ pacjentem oraz uprawnienia dające pracownikom możliwość zamiany ról w razie potrzeby (poziom zasobów ludzkich).

- Na poziomie dostarczania świadczeń istotna jest rola koordynatora opieki, który ma zarządzać skierowaniami i umożliwiać skuteczną realizację celów programu.

- Plany opieki powinny być ,szyte na miarę”, to jest dostosowane do indywidualnych potrzeb danego użytkownika. Nie należy z góry narzucać wcześniej opracowanego planu opieki, ponieważ potrzeby pacjenta mogą z czasem zmieniać się, a wraz z nimi powinien elastycznie ewoluować tryb realizacji świadczeń.

- Wydaje się, że skuteczność poprawia się, gdy celem jest zapewnienie pacjentowi dobrostanu/niezależności w codziennym funkcjonowaniu i wspieranie go w taki sposób, aby mógł sobie radzić ze schorzeniem i prowadzić dobre życie, w odróżnieniu od podejścia nastawionego wyłącznie na ograniczanie/leczenie objawów (poziom osobisty).

\section{Podsumowanie}

Podsumowując doświadczenia międzynarodowe, należy podkreślić, że modeli międzynarodowych nie da się przenieść w całości na grunt polski. Osoby odpowiedzialne za wdrażanie programu opieki koordynowanej w różnych krajach niemal jednogłośnie twierdzą, że „doświadczeń zdobytych podczas procesu tworzenia i wdrażania programu nie da się niczym zastąpić”, gdyż kluczem do sukcesu są przede wszystkim alianse i sieci kontaktów budowane i rozwijane w trakcie samego procesu. Przy wykorzystywaniu doświadczeń z innych podobnych programów niezbędna jest dogłębna, oparta na dowodach znajomość lokalnego kontekstu i uwarunkowań.

Postępy we wdrażaniu opieki koordynowanej są szybsze, gdy instytucje wdrażające opiekę działają w ramach coraz mocniej zintegrowanego systemu realizacji świadczeń, to znaczy, gdy procesy zakupu, planowania, organizacji i nadzoru nad realizacją świadczeń przebiegają w jak najbardziej zbliżony i zharmonizowany sposób.

Należy zwrócić większą uwagę na szczegółowy monitoring oraz analizę wyników wdrażania i stosowania koordynowanego systemu organizacji dostarczania świadczeń zdrowotnych nie tylko pod kątem uzasadnienia poniesionych inwestycji, lecz także pod względem rozważenia jakości oferowanej opieki.

W Polsce w celu dalszego rozwoju systemów dostarczania usług zdrowotnych wokół pacjenta przydatne mogą być: 
- analiza danego problemu i wspólnej zgody dotyczącej jego rozwiązywania - wspólnego celu;

- myślenie długofalowe, ale praktyczne (ewolucja, nie rewolucja);

- zrozumienie i zaangażowanie różnych środowisk i ich liderów, w tym lidera opieki koordynowanej;

- zmiana myślenia o systemie ochrony zdrowia i roli jego uczestników, łącznie ze zmianą roli pacjenta w systemie i samoopieki (self care);

- narzędzia (wiedzy, podręczników, wskazówek) i fundusze wspierające to wdrożenie;

- systemy informacyjne/informatyczne.

Projektowanie i wdrażanie opieki koordynowanej wymaga znacznych inwestycji w zasoby ludzkie, wiedzy i czasu, aby model ten odniósł sukces. Przykłady z całego świata również podkreślają, że opieka koordynowana jest długoterminową strategią zmian i rozwoju. Aby uzyskać wsparcie i chęć uczestnictwa ludzi, specjalistów i decydentów, koordynator musi określić wspólne korzyści i zbudować koalicję na rzecz ich realizacji. Od samego początku konieczne są też jasne i mierzalne założenia oraz ramy dla oceny, a także w odniesieniu do nich ustanowienie zewnętrznej (naukowej) oceny i publikacja rezultatów. Narzędzia wdrożenia, edukacja i szkolenie kadr, pacjentów i społeczności wspiera równie niezbędne zmiany kulturowe, jak również budowanie umiejętności (capacity building) w celu świadczenia i aktywnego uczestnictwa w tych nowych procesach. Kliniczne i administracyjne przywództwo, silne struktury koordynujące oraz właściwe zachęty motywacyjne są konieczne, aby zapewnić zrównoważony rozwój transformacji oraz odporność na zewnętrzne zmiany, takie jak zmiany przepisów czy cięcia budżetowe.

Skupienie się na holistycznych potrzebach obywateli powinno być nadrzędną zasadą dla systemu, w którym regulacje, struktury prawne, organizacyjne i finansowe wspomagają lokalną innowację zgodnie z potrzebami mieszkańców i społeczności oraz przy ich współpracy, a nie są przeszkodą w rozwoju.

\section{Przypisy}

${ }^{1}$ Model tęczy to graficznie opracowana definicja przedstawiająca mechanizmy i wymiary opieki koordynowanej.

${ }^{2}$ Gesundes Kinzingtal to regionalna niemiecka firma będąca dostarczycielem usług zdrowotnych, instytucją badawczą, która w literaturze przedmiotu pojawia się, oferując jeden z modeli opieki koordynowanej. Model ten jest dobrze opisany i przeanalizowany.

\section{Piśmiennictwo}

1. Melchiorre M.G. et al., eHealth in integrated care programs for people with multimorbidity in Europe: Insights from the ICARE4EU project, Health Policy 2017.

2. Rijken M., Struckman V., How to Improve Care for People with Multimorbidity in Europe?, Nivel and Tu, Berlin 2016.

3. WHO Regional Office for Europe, Strengthening Peoplecentered Health Systems in the WHO European Region:
Framework for Action on Integrated Health Services Delivery, Copenhagen 2016.

4. AHRQ, Closing the Quality Gap: A Critical Analysis of Quality Improvement Strategies (Vol 7; Care Coordination), Agency for Healthcare Research and Quality Report, Rockville 2007.

5. Kodner D., Spreeuwenberg C., Integrated care: Meaning, logic, applications and implications - a discussion paper, „International Journal of Integrated Care” 2002; 2 (3).

6. Berwick D., What „patient-centered” should mean: Confessions of an extremist, „Health Affairs” 2009; 28 (4): 560-562.

7. Blount A., Integrated primary care: Organizing the evidence, „Families, Systems, \& Health” 2003; 21 (2).

8. Doherty W.J., McDaniel S.H., Baird M.A., Five levels of primary care/behavioral healthcare collaboration, ,Behavioral Healthcare Tomorrow" 1996; 5: 25-28.

9. Haas L.J., deGruy F.V., Primary care, psychology, and primary care psychology, w: Haas L.J. (red.), Handbook of Primary Care Psychology, Oxford University Press, New York 2004: 5-19.

10. Hunter C.L., Goodie J.L., Oordt M.S., Dobmeyer A.C., Integrated Behavioral Health in Primary Care: Step-by-Step Guidance for Assessment and Intervention, American Psychological Association, Washington 2009.

11. Kates N., Craven M.A., Crustolo A.M., Nikolaou L., Allen C., Farrar S., Sharing care: The psychiatrist in the family physician's office, „Canadian Journal of Psychiatry” 1997; 42 (9): 960-965.

12. Kelly B., Perkins D., Fuller J., Parker S., Shared care in mental illness: A rapid review to inform implementation, „International Journal of Mental Health Systems” 2011; 5 (31).

13. Robinson P., Reiter J., Behavioral Consultation and Primary Care: A Guide to Integrating Services, Springer Science + Business Media, New York 2007.

14. Sabin J.E., Borus J.F., Changing roles in primary behavioral healthcare, w: Talbot J.A., Hales R.E. (red.), Textbook of Administrative Psychiatry: New Concepts for a Changing Behavioral Health System, American Psychiatric Publishing, Inc., Washington 2009.

15. Unützer J., Katon W., Callahan C., Williams J., Hunkeler E., Harpole L., Hoffing M., Della Penna R., Hitchcok N., Lin E., Areán P., Hegel M., Tang L., Belin T., Oishi S., Langston C., Collaborative care management of late-life depression in the primary care setting: A randomized controlled trial, „JAMA” 2002; 288 (22): 2836-2845.

16. Øvretveit J., Integrated Care: Models and Issues, Briefing Paper, The Nordic School of Public Health, Gothenburg 1998.

17. Leutz W.N., Five laws for integrating medical and social services: Lessons from the United States and the United Kingdom, „The Milbank Quarterly” 1999; 77 (1): 77-110.

18. Gröne O., Garcia-Barbero M., Integrated care: A position paper of the WHO European Office for Integrated Health Services, „International Journal of Integrated Care” 2001; 1 (21).

19. Nolte E., McKee M., Integration and chronic care: A review, w: Nolte E., McKee M. (red.), Caring for People with Chronic Conditions. A Health System Perspective, World 
Health Organization on behalf of the „European Observatory on Health Systems and Policies” 2008: 64-91.

20. Fulop N., Mowlem A., Edwards N., Building Integrated Care: Lessons from the UK and Elsewhere, The NHS Confederation, London 2005.

21. Shortell S., Gillies R., Anderson D., Morgan K., Mitchell J., Remaking Health Care in America: The Evolution of Organized Delivery Systems, $2^{\text {nd }}$ ed., The Jossey-Bass Health Care Series, San Francisco 2000.

22. Valentijn P.P., Schepman S.M., Opheij W., Bruijnzeels M.A., Understanding integrated care: A comprehensive conceptual framework based on the integrative functions of primary care, „International Journal of Integrated Care” 2013; 13.

23. Valentijn P.P., Boesveld I.C., van der Klauw D.M., Ruwaard D., Struijs J.N., Molema J.J.W., Bruijnzeels M.A., Vrijhoef H.J.M., Towards a taxonomy for integrated care: A mixedmethods study, „International Journal of Integrated Care” 2015; 15 (1).

24. Ferrer L., Engaging Patients, Carers and Communities for the Provision of Coordinated/Integrated Health Services: Strategies and Tools, WHO Regional Office for Europe, Copenhagen 2015.

25. Kodner D., Kyriacou C.K., Fully integrated care for the frail elderly: Two American models, „International Journal of Integrated Care" 2000; 1 (1).

26. Reiss-Brennan B., Brunisholz K.D., Dredge C., Briot P., Grazier K., Wilcox A., Savitz L., James B., Association of integrated team based care with health quality, utilization and cost, ,JAMA” 2016; 316 (8): 826-834.

27. Dorling G., Founaine T., McKenna S., Suresh B., The Evidence for Integrated Care, McKinsay \& Company, London, 015.

28. Runz-Jørgensen S., Frølich A., SIKS - the integrated effort for people living with chronic diseases. A case study of people centred/integrated health care in Denmark, The Research Unit for Chronic Conditions, Bispebjerg Hospital, Copenhagen 2015.
29. Powell-Davies G., Williams A.M., Larsen K., Perkins D., Roland M., Harris M.F., Coordinating primary health care: An analysis of the outcomes of a systematic review, „The Medical Journal of Australia" 2008; 188 (8).

30. Peikes D., Chen A., Schore J., Brown R., Effects of Care Coordination on Hospitalization, Quality of Care, and Health Care Expenditures Among Medicare Beneficiaries: 15 Randomized Trials, „JAMA” 2009; 301 (6).

31. Sochalski J., Jaarsma T., Krumholz H.M., Laramee A., McMurray J.J.V., Naylor M.D., Rich M.W., Riegel B., Stewart S., What works in chronic care management: The case of heart failure, „Health Affairs” 2009; 28 (1).

32. Mattke S., Seid M., Ma S., Evidence for the effectiveness of disease management: Is $\$ 1$ billion a year a good investment?, „American Journal of Managed Care” 2007; 13 (12).

33. Hildebrandt H., Schulte T., Stunder B., Triple aim in Kinzigtal, Germany. Improving population health, integrating health care and reducing costs of care - lessons for the UK?, „Journal of Integrated Care” 2013; 20 (4): 205-222.

34. CareFirst BlueCross BlueShield's Patient-Centered Medical Home Program: An Overview, https://member.carefirst. com/carefirst-resources/pdf/pcmh-program-overview.pdf (dostęp: 9.09.2017).

35. Goodwin N., Dixon A., Anderson G., Wodchis W., Providing Integrated Care for Older People with Complex Needs: Lessons from Seven International Case Studies, The King's Fund, London 2014.

36. Registered Nurses Association of Ontario [RNAO], Strategies to Support Self-management in Chronic Conditions' Collaboration with Clients, International Affairs Clinical Best Practices Guidelines, Toronto 2010.

37. Bank Światowy, Strategia wdrażania opieki koordynowanej, Waszyngton 2017.

38. Goodwin N., Senola L., Thiel V., Co-ordinated Care for People with Complex Chronic Conditions: Key Lessons and Markers for Success, The King's Fund, London 2013. 